\title{
SEMIOTIKA DAN RELEVANSINYA DENGAN KAJIAN AL-QUR'AN
}

\author{
Abdul Wadud Kasful Humam \\ STAI Al-Anwar Sarang-Rembang \\ kasyful_humam@yahoo.co.id
}

\begin{abstract}
Considering that the Qur'an consists of a series of Arabic letters arranged in strings of words and sentences, is a medium where signs are messy, so one approach that seems interesting and relevant is the semiotic approach which examines how sign works and its function in the text of the Qur'an. Semiotics is a discipline that examines signs found in society. Meanwhile, the Al-Qur'an using language as a medium is fertile ground for semiotic studies. In the Qur'an, there are signs that their meanings can be studied by using semiotics. The Qur'an has basic units called verses (signs). Signs in the Qur'an are not only small parts of the elements, such as sentences, words or letters, but the totality of the structures that connect each element is included in the category of signs of the Qur'an. This shows that the entire form of the Qur'an is a series of signs that have meaning.
\end{abstract}

Keywords: Semiotics, al-Qur'an, Sign.

\begin{abstract}
Abstrak
Pertimbangan bahwa al-Qur'an terdiri dari rangkaian huruf-huruf Arab serta tersusun dalam untaian kata-kata dan kalimat, merupakan media tempat carut marutnya tanda-tanda, maka salah satu pendekatan yang agaknya menarik dan relevan adalah pendekatan semiotik yang mengkaji bagaimana cara kerja dan fungsi tanda-tanda dalam teks al-Qur'an. Semiotika sendiri merupakan displin ilmu yang mengkaji tanda-tanda, yaitu tanda-tanda yang terdapat di dalam masyarakat. Sementara itu, al-Qur'an dengan menggunakan bahasa sebagai media merupakan lahan subur bagi kajian semiotika. Dalam al-Qur'an, terdapat tanda-tanda yang memiliki arti, yang dapat dikaji dengan menggunkan semiotika. Al-Qur'an memiliki satuan-satuan dasar yang dinamakan ayat (sign). Tanda dalam al-Qur'an tidak hanya bagian-bagian kecil dari unsurunsurnya, seperti kalimat, kata atau huruf, tetapi totalitas struktur yang menghubungkan masing-masing unsur termasuk dalam kategori tanda alQur'an. Hal ini menunjukkan bahwa seluruh wujud al-Qur'an adalah serangkaian tanda-tanda yang memiliki arti.
\end{abstract}

Kata Kunci: Semiotika, al-Qur'an, Tanda-Tanda 


\section{A. Pendahuluan}

Semiotika merupakan cabang keilmuan modern yang mengkaji sistem tanda. Dalam pengertian yang lebih luas, semiotika berarti studi sistematis mengenai produksi atau interpretasi tanda, cara kerja dan manfaatnya dalam kehidupan manusia. Kehidupan manusia sangat dipenuhi oleh tanda, dengan perantara tanda-tanda proses kehidupan lebih efisien. Tanda-tanda ini menjadi perantara bagi komunikasi manusia dengan sesamanya, sekaligus mengadakan pemahaman yang lebih baik terhadap dunia, sehingga manusia pun bisa disebut sebagai homo semioticus dan animal simbolicum. ${ }^{1}$

Walaupun dua ribu tahun yang lalu para ahli filsafat Yunani sekali-kali sudah memikirkan fungsi tanda dan di dalam filsafat Yunani abad pertengahan pengertian serta penggunaan tanda telah disinggung-singgung, istilah semiotika sendiri baru digunakan pada abad XVII oleh Lambert, seorang ahli filsafat Jerman. Orang baru memikirkan secara sistematis tentang penggunaan tanda dan ramai membahasnya dalam abad XX ini. Misalnya Roland Barthes, L.J. Prieto, J. Kristeva, G. Mounin, dan lain-lain.

Adalah Umberto Eco pada tahun 1976 telah menerbitkan bukunya yang berjudul $A$ Theory of Semiotics yang antara lain memuat pemikirannya tentang batas-batas penelitian semiotika. Bunga rampai yang ditulis Eco sejalan benar dengan gagasan yang ditulis Peirce, sebagian besar tulisan Roman Jokobson "Linguistics and Poetics dengan skema komunikasinya yang terkenal, dan fragmen tulisan Roland Barthes. Dan Eco pada kesimpulan bahwa semiotika terbagi menjadi semiotika signifiaksi dan semiotika komunikasi. ${ }^{2}$

Dan dalam perkembangannya, semiotik kemudian dijadikan sebagai alat untuk mendekati Al-Qur'an, karena Al-Qur'an sarat dengan tanda-tanda dan simbol-simbol kebahasaan, sehingga untuk mendapatkan meaning dan significance sistem tanda yang ada di dalamnya harus dikaji. Adalah Muhammad Arkoun dan Nashr Hamid telah megaplikasikan pendekatan ini di dalam menafsirkan Al-Qur'an.

\section{B. Semiotika; Tinjauan Terminologis}

Secara etimologis, istilah semiotika berasal dari kata yunani semeion yang berarti "tanda". Atau "seme" yang berarti penafsiran tanda. Semiotika adalah ilmu tanda yaitu metode analisis untuk mengkaji tanda. Tanda-tanda adalah perangkat yang dipakai dalam

\footnotetext{
${ }^{1}$ Alex Sobur, Semiotika Komunikasi (Bandung: PT. Remaja Rosdakarya, 2006), 14.

${ }^{2}$ Panuti Sudjiman dan Aart Van Zoest, Serba-Serbi Semiotika (Jakarta: Gramedia Pustaka Utama, 1992), Vii.
} 
Semiotika dan Relevansinya dengan Kajian Al-Qur'an Abdul Wadud Kasful Humam

Doi: doi.org/10.47454/itqan.v4i1.677

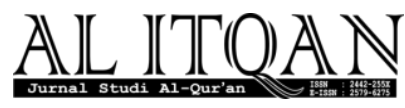

upaya mencari jalan di dunia, di tengah-tengah manusia, bersama manusia. ${ }^{3}$ Tanda itu sendiri didefinisikan sebagai sesuatu yang atas dasar konvensi sosial yang terbangun sebelumnya, dapat dianggap mewakili sesuatu yang lain. Tanda pada awalnya dimaknai sebagai suatu hal yang menunjuk pada adanya hal lain. Contohnya asap menandai adanya api, sirene mobil yang keras meraung-raung menandai adanya kebakaran di sudut kota. ${ }^{4}$

Tanda terdapat di mana-mana: kata adalah tanda, demikian pula gerak isyarat, lampu lalu lintas, bendera, dan sebagainya. Struktur karya sastra, struktur film, bangunan atu nyanyian burung dapat dianggap sebagai tanda. Charles Sanders Peirce, menegaskan bahwa kita hanya dapat berpikir dengan sarana tanda. Sudah pasti bahwa tanpa tanda kita tidak dapat berkomunikasi. $^{5}$

Lebih jelas lagi, kita banyak mengenal tanda-tanda dalam kehidupan berkeluarga dan bermasyarakat. Misalnya, bila di sekitar rumah kita ada tetangga yang memasang janur (penanda), maka itu pertanda ada hajatan perkawinan (petanda), tetapi bila terpasang bendera warna kuning di depan rumah dan sudut jalan (penanda), maka itu pertanda ada kematian (petanda). Bagi etnis tertentu seperti warga keturunan Cina di Jakarta, justru menggunakan warna putih dari kain blacu untuk menandakan mereka merasa sangat kehilangan dan ditinggalkan orang yang mereka kasihi. Bahkan di jendela atau pintu rumah mereka ada tanda garis miring satu atau silang untuk menunjukkan siapa yang meninggal. Bila hanya ada satu garis itu berarti istri atau suami atau orang tua yang meninggal, sedangkan bila terdapat dua garis, maka kedua orang tua atau suami-istri yang ada di rumah tersebut sudah meninggal. ${ }^{6}$

Sedangkan secara terminologis, Umberto Eco mendefinisakan semiotika sebagai ilmu yang mempelajari sederetan objek, peristiwa-peristiwa, dan seluruh kebudayaan sebagai tanda (sign). Dan menurut Eco, ada sembilan belas bidang yang bisa dipertimbangkan sebagai bahan kajian untuk semiotik, yaitu semiotik binatang, semiotik tanda-tanda bauan,

\footnotetext{
${ }^{3}$ Kaelan, Filsafat Bahasa Semiotika dan Hermeneutika (Yogyakarta: Paradigma, 2009), 157.

${ }^{4}$ Indiwan Seto Wahyu Wibowo, Semiotika; Aplikasi Praktis bagi Penelitian dan Penulisan Skripsi Ilmu Komunikasi (Jakarta: Fakultas Ilmu Komunikasi, 2006), 7.

5 "Kata Pengantar" dalam Panuti Sudjiman dan Aart Van Zoest, Serba-Serbi Semiotika (Jakarta: Gramedia Pustaka Utama, 1992), Vii.

${ }^{6}$ Indiwan Seto Wahyu Wibowo, Semiotika; Aplikasi Praktis bagi Penelitian dan Penulisan Skripsi Ilmu Komunikasi, 7. Contoh-contoh ini jika ditarik dalam kajian Al-Qur'an, bahwa penanda adalah teks Al-Qur'an yang berupa bahasa Arab, meliputi huruf, kata, kalimat, ayat, surat maupun struktur yang lebih luas. Sedangkan petandanya adalah aspek mental atau konsep yang berada di balik penanda Al-Qur'an. Ali Imron "Kisah Nabi Yusuf Dalam Al-Qur'an; Kajian Semiotik", tesis Pasca Sarjana UIN Sunan Kalijaga Yogyakarta, konsentrasi Studi Al-Qur'an dan Hadis, 2010, 343.
} 
komunikasi rabaan, kode-kode cecapan, paralinguistik, semiotik medis, kinesik dan proksemik, kode-kode musik, bahasa yang diformalkan, bahasa tertulis, alfabet tak dikenal, kode rahasia, bahasa alam, komunikasi visual, sistem objek, dan sebagainya Semiotika di bidang komunikasi pun juga tidak terbatas, misalnya saja bisa mengambil objek penelitian, seperti pemberitaan di media massa, komunikasi periklanan, tanda-tanda non-verbal, film, komik kartun, dan sastra sampai kepada musik. ${ }^{7}$

Sementara Aart Van Zoest mendefinisikan semiotik sebagai cabang ilmu yang berurusan dengan dengan pengkajian tanda dan sesuatu yang berhubungan dengan tanda, seperti sistem tanda dan proses yang berlaku bagi tanda. ${ }^{8}$ Dan Charles Shanders Peirce mendifiniskan semiotik dengan ilmu yang mempelajarai tentang tanda (sign), fungsi tanda dan produksi makna. Tanda-tanda tersebut menyampaikan suatu informasi sehingga bersifat komunikatif. Ia mampu menggantikan suatu yang lain yang dapat dipikirkan atau dibayangkan. Cabang ilmu ini semua berkembang dalam bidang bahasa kemudian berkembang pula dalam bidang seni rupa dan desain komunikasi visual. ${ }^{9}$

\section{Semiotika: Tinjaun Historis}

Walaupun dua ribu tahun yang lalu para ahli filsafat Yunani sekali-kali sudah memikirkan fungsi tanda dan di dalam filsafat Yunani abad pertengahan pengertian serta penggunaan tanda telah disinggung-singgung, istilah semiotika sendiri baru digunakan pada abad XVII oleh Lambert, seorang ahli filsafat Jerman. Orang baru memikirkan secara sistematis tentang penggunaan tanda dan ramai membahasnya dalam abad XX ini. Misalnya Roland Barthes dengan bukunya Elements de Semiologie, L.J. Prieto dalam bukunya Messages et Signaux, J. Kristeva di dalam Semeiotike, G. Mounin di dalam buku Introduction a la Semiologie.

Umberto Eco pada tahun 1976 telah menerbitkan bukunya yang berjudul $A$ Theory of Semiotics yang antara lain memuat pemikirannya tentang batas-batas penelitian semiotika. Bunga rampai yang ditulis Eco sejalan benar dengan gagasan yang ditulis Peirce, sebagian besar tulisan Roman Jokobson "Linguistics and Poetics dengan skema komunikasinya yang

\footnotetext{
7 Panuti Sudjiman dan Aart Van Zoest, Serba-Serbi Semiotika, hlm. 34-42. Lihat Alex Sobur, Semiotika Komunikasi, hlm. 12-13.

${ }^{8}$ Aart Van Zoest, Semiotika; Tentang Tanda, Cara Kerjanya dan Apa yang Kita Lakukan dengannya (Jakarta: Yayasan Sumber Agung, 1993), hlm. 1.

${ }^{9}$ Sumbo Tinarbuko, Semiotika Komunikasi Visual (Yogyakarta: Jalasutra, 2008), hlm. 16.
} 
Semiotika dan Relevansinya dengan Kajian Al-Qur'an Abdul Wadud Kasful Humam

Doi: doi.org/10.47454/itqan.v4i1.677

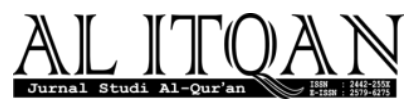

terkenal, dan fragmen tulisan Roland Barthes. Bahkan Ch. S Peirce telah lebih dulu mengetengahkan teorinya tentang semiotika, yaitu pada tahun 1931 .

Bidang ini kemudian menjadi lahan yang subur, dan bermunculanlah bebagai tulisan tentang semiotika seperti tulisan Ch. Morris Writings on the General Theory of Sign, R. Jakobson Coup d'Oeil sur le Developpement de la Semiotique dan T.A. Sebeok Contribution to the Doctrine of Sign. ${ }^{10}$

\section{Semiotika; Teori Dusta (Theory of The Lie)}

Umberto Eco, pakar semiotik sekaligus kritikus sastra asal Italia mengatakan bahwa semiotika adalah sebuah disiplin yang mempelajari segala sesuatu yang dapat digunakan untuk berdusta (lie). Bila sesuatu tidak dapat digunakan untuk mengungkapkan dusta, maka sebaliknya ia tidak dapat juga digunakan untuk mengungkapkan kebenaran (truth); Ia pada kenyataannya tidak dapat digunakan untuk mengungkapkan apa-apa. Saya pikir definisi sebagai sebuah teori kedustaan sudah sepantasnya diterima sebagai sebuah program komprehensif untuk semiotika umum (general semiotics). ${ }^{11}$

Ada pesan implisit dari definisi yang dikemukakan Eco, bahwa teori yang mampu mengungkap dusta, pasti bisa mengungkap kebenaran. Sebab, apabila sebuah tanda tidak dapat digunakan untuk mengungkap kebenaran, maka disaat yang bersamaan ia juga tidak dapat pula digunakan untuk mengungkap kedustaan. Jika pernyataan Eco tersebut dikaitkan dengan semiotika antara tanda (sign), makna (petanda) dan realitas (reference), adalah mengatakan atau menulis sesuatu yang kita tahu itu tidak benar, yang berarti bahwa antara yang dikatakan atau yang ditulis tidak sesuai dengan realitas. Atau dengan kata lain, dalam tanda tersebut terdapat dusta sekaligus kebenaran.

Logika sederhananya, ketika seseorang mempromosikan produk $\mathrm{X}$ bisa mengobati berbagai macam penyakit hanya dalam hitungan menit saja, itu bukan berarti untuk menunjukkan kebenaran yang sesungguhnya. Akan tetapi, ada pesan implisit di balik katakata tersebut, bahwa produk $\mathrm{X}$ memang mengandung kebenaran, yaitu bisa mengobati penyakit. Karena di dalam dunia promosi atau iklan, menjadikan segala sesuatu yang tidak mungkin menjadi mungkin.

\section{E. Antara Semiotika dan Semiologi}

\footnotetext{
${ }^{10}$ Panuti Sudjiman dan Aart Van Zoest, Serba-Serbi Semiotika, vii-viii.

11 Yasraf Amir Piliang, Hipersemiotika Tafsir Cultural Studies Atas Matinya Makna (Yogyakarta: Jalasutra, 2010), 45.
} 
Istilah lain untuk menyebut semiotika adalah semiologi. Penggunaan dua istilah ini hanya menandai pengaruh dari dua kubu aliran semiotika; aliran Pierce dan Saussure. Seseorang akan lebih suka menyebut dan memakai istilah semiologi, jika ia berpihak pada tradisi Saussurian (Ferdinand de Saussure), sedangkan istilah semiotika akan banyak digunakan oleh penggemar dan pengagum tradisi Charles Sanders Pierce.

Hanya saja, penggunaan istilah "semiologi" pada akhir-akhir ini jarang dipakai ketimbang istilah "semiotika". 12 Sampai-sampai Tommy Christomy mengatakan bahwa ada kecenderungan istilah semiotika lebih populer daripada istilah semiologi, sehingga para penganut Sausssurian pun sering menggunakannya.

Sedangkan menurut Hawkes, perbedaan istilah tersebut adalah bahwa istilah semiologi biasanya digunakan di Eropa, sementara semiotika cenderung dipakai oleh mereka yang berbahasa Inggris. ${ }^{13}$ Dengan kata lain, penggunaan terminologi semiologi lebih tertuju pada kubu Saussure, sedangkan semiotika lebih cenderung pada kubu Peirce. Keputusan untuk memakai istilah semiotika, menurut Umberto Eco adalah sesuai dengan resolusi yang diambil komite Internastional di Paris pada Januari 1969. Pilihan ini kemudian dikukuhkan oleh Assosiation for Semiotik Studies pada konggresnya yang pertama pada tahun $1974 .^{14}$

\section{F. Relevansi Semiotika Terhadap Kajian Islamic Studies}

Saat ini, pergulatan dalam ranah kajian tafsir kontemporer menuntut adanya suatu model tafsir yang membebaskan. Tafsir yang tidak hanya didominasi oleh sebagian golongan tertentu, tetapi juga menampung aspirasi dan pendapat kelompok-kelompok yang selama ini tersubordinatkan. Ini dapat dilihat dengan munculnya beragam pendekatan baru dalam kajian tafsir, seperti hermeneutika, sastra, teologi pembebasan dan lain-lain.

Dengan pertimbangan bahwa Al-Qur'an terdiri dari rangkaian huruf-huruf Arab serta tersusun dalam untaian kata-kata dan kalimat, merupakan media tempat carut marutnya tandatanda, maka salah satu pendekatan yang agaknya menarik dan relevan adalah pendekatan semiotik yang mengkaji bagaimana cara kerja dan fungsi tanda-tanda dalam teks Al-Qur'an. ${ }^{15}$

\footnotetext{
${ }^{12}$ Aart Van Zoest, Semiotika; Tentang Tanda......., 2.

${ }^{13}$ Alex Sobur, Semiotika Komunikasi, 12.

${ }^{14}$ Ibid., , 13.

${ }^{15}$ Semiotika berbeda dengan hermenutika. Pendekatan hermenutika dalam tafsir Al-Qur'an menuntut tiga fokus utama yang selalu dipertimbangkan, yaitu dunia teks, pengarang dan pembaca. Sedangkan semiotik membahas sesuatu yang lebih spesifik. Jika hermeneutika memberikan fokus cukup luas yang mencakup teks, pembacaan, pemahaman, tujuan penulisan, konteks, situasi historis dan kondisi psikologis pembaca maupun pengranag teks.
} 
Semiotika dan Relevansinya dengan Kajian Al-Qur'an

Abdul Wadud Kasful Humam

Doi: doi.org/10.47454/itqan.v4i1.677

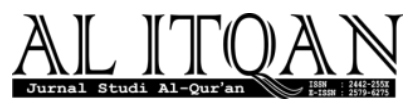

Semiotika merupakan displin ilmu yang mengkaji tanda-tanda, yaitu tanda-tanda yang terdapat di dalam masyarakat. Sementara itu, Al-Qur'an dengan menggunakan bahasa sebagai media merupakan lahan subur bagi kajian semiotika. Dalam Al-Qur'an, terdapat tanda-tanda yang memiliki arti, yang dapat dikaji dengan menggunkan semiotika. Al-Qur'an memiliki satuan-satuan dasar yang dinamakan ayat (sign). Tanda dalam Al-Qur'an tidak hanya bagianbagian kecil dari unsur-unsurnya, seperti kalimat, kata atau huruf, tetapi totalitas struktur yang menghubungkan masing-masing unsur termasuk dalam kategori tanda Al-Qur'an. Hal ini menunjukkan bahwa seluruh wujud Al-Qur'an adalah serangkaian tanda-tanda yang memiliki arti. $^{16}$

Salah satu contoh adalah kisah Nabi Yusuf dalam surat Yusuf ayat 4 dan seterusnya:

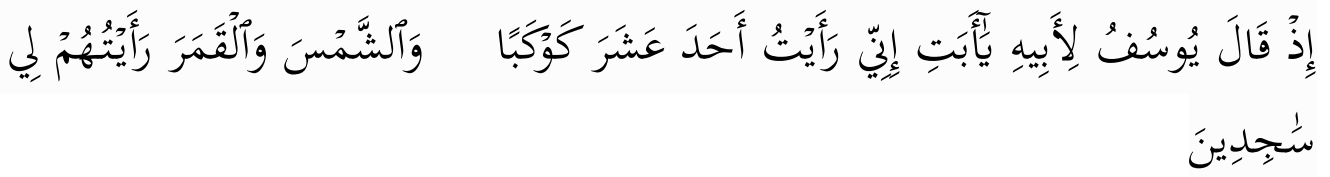

Kata "Yusuf" pada permulaan cerita merupakan tanda penting yang mengacu pada tokoh central cerita. Beliau adalah tokoh protagois yang menjadi tokoh utama dan melakukan hubungan dengan tokoh-tokoh lain. Sementara itu, mimpi mengenai sebelas bintang, matahari dan bulan yang bersujud pada Yusuf merupakan simbol tertentu. ${ }^{17}$

Mimpi Nabi Yusuf tentang aḥada 'asyara kaukabā, al-syams, al-qamar dan al-sājidīn merupakan tanda-tanda yang mengacu pada sebelas bintang, matahari, bulan, dan aktifitas sujud dalam pengertian denotatif. Nabi Ya'qub mempunyai dua istri; Leah dan Rachel dan dua orang gundik; Bilhah dan Zilpah. Empat perempuan ini melahirkan anak-anak Ya'qub sebanyak 12 anak, yaitu: Ruben, Simeon, Lewi, Yehuda, Issachar, Zebulun, Yusuf, Benyamin, Dan, Naphtali, Gad dan Asher.

Tanda ahada 'asyara kaukabā merupakan simbol dari sebelas saudara Nabi Yusuf, alqamar simbol Ya'qub, ayah Nabi Yusuf, sedangkan al-sayms adalah simbol ibu Nabi Yusuf. Sementara itu, al-sājidīn adalah simbol ketundukan orang-orang tersebut kepada beliau.

Hubungan antara penanda dan makna dihasilkan sesuai dengan faktor kemiripan atau prperti. Hubungan ini emrupakan hubungan ikonik. Sebelas bintang dimaknai saudara-

\footnotetext{
Maka, semiotika mempersempit wilayah kajian tersebut dengan hanya memberikan fokus pembahasan hanya tentang tanda, fungsi, dan cara kerjanya. Mu'adz Fahmi "Semiotika Al-Qur'an yang Membebaskan” dalam Jurnal kolom edisi 046, Februari 2012, 3-5.

${ }^{16}$ Ali Imran, Kisah Nabi Yusuf Dalam Al-Qur'an; Kajian Semiotik (Yogyakarta: Teras, 2011), 33-34.

${ }^{17}$ Ibid., 56.
} 
saudara Yusuf, karena memiliki kesamaan properti dalam jumlah bilangan. Matahari merupakan benda yang selalu memberikan kehangatan, kehidupan, dan menyinari bumi. Begitu pula Ya'qub, selalu memberikan kehangatan dan kasih sayang seolah matahari menyinari bumi. Bulan benda langit terlihat indah di malam hari dan memancarkan kelembutan. Itulah gambaran seorang ibu.

Penggunaan simbol sebelas bintang, matahari, dan bulan juga memiliki pembacaan semiotik lain. Semua tanda tersebut adalah benda-benda langit yang sangat tinggi. Tandatanda itu merupakan simbol dari sesuatu "tinggi" yang bersujud kepada Yusuf. Hal ini bermakna tingginya derajat dan kedudukan yang akan diperoleh Yusuf, sehingga membuat benda-benda langit bersujud kepadanya, sebagai bentuk gambaran ketinggian dan kemuliaan yang diraih oleh Yusuf. ${ }^{18}$

Contoh lainnya adalah rukun ibadah haji (melontar jumrah). Melontar jumrah adalah salah satu bentuk pertandaan yang merupakan tiruan ikonik Nabi Ibrahim yang melempari Iblis yang mengganggunya. Walaupun dengan asumsi makna yang sama, yaitu "mengusir Iblis", akan tetapi penanda (melempar kerikil) tidak bisa dengan sewenang-wenang diganti secara kreatif, misalnya dengan ketapel, panah atau pistol, meskipun semuanya boleh jadi akan menggiring pada makna ideologis ketinggian derajat manusia. Hal yang sama juga berlaku pada rukun shalat, misalnya rukun sujud diganti hanya dengan ibadah dalam hati. Merubah tanda yang telah eksplisit kodenya akan merubah makna ibadah itu sendiri. ${ }^{19}$

\section{G. Kesimpulan}

Semiotika adalah disiplin ilmu yang mempelajari sederetan objek, peristiwaperistiwa, dan seluruh kebudayaan sebagai tanda (sign). Tanda itu sendiri adalah didefinisikan sebagai sesuatu yang atas dasar konvensi sosial yang terbangun sebelumnya, dapat dianggap mewakili sesuatu yang lain. Tanda pada awalnya dimaknai sebagai suatu hal yang menunjuk pada adanya hal lain.

Menurut Eco, ada sembilan belas bidang yang bisa dipertimbangkan sebagai bahan kajian untuk semiotik, yaitu semiotik binatang, semiotik tanda-tanda bauan, komunikasi rabaan, kode-kode cecapan, paralinguistik, semiotik medis, kinesik dan proksemik, kode-kode musik, bahasa yang diformalkan, bahasa tertulis, alfabet tak dikenal, kode rahasia, bahasa

\footnotetext{
${ }^{18}$ Ibid.,, 188-189.

${ }^{19}$ Yasraf Amir Piliang, Hipersemiotika Tafsir Cultural Studies Atas Matinya Makna, 308.
} 
Semiotika dan Relevansinya dengan Kajian Al-Qur'an

Abdul Wadud Kasful Humam

Doi: doi.org/10.47454/itqan.v4i1.677

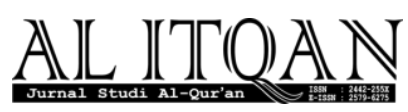

alam, komunikasi visual, sistem objek, dan sebagainya Semiotika di bidang komunikasi pun juga tidak terbatas, misalnya saja bisa mengambil objek penelitian, seperti pemberitaan di media massa, komunikasi periklanan, tanda-tanda non-verbal, film, komik kartun, dan sastra sampai kepada musik.

Sebagai kelanjutan dari teori semiologi Ferdinand de Saussure dan semiotika Charles Sanders Pierce, Umberto Eco mengklasifikasikan semiotik sebagai kajian menjadi dua; siginifikasi dan komunikasi. Bagian pertama banyak didapati dalam teori semiologi Saussure, sedangkan yang kedua banyak diwakili teori semiotika Pierce, yaitu semiotika siginifikasi dan semiotika komunikasi.

Kemudian dalam perkembangannya, semiotika digunakan sebagai alat untuk mendekati Al-Qur'an, karena Al-Qur'an sarat dengan tanda-tanda dan simbol-simbol yang makna dan artinya akan dapat digali dengan cara mengkaji semiotik. Di antaranya adalah kisah mimpi Nabi Yusuf tentang sebelas bintang, matahari dan bulan yang semuanya sujud kepadanya dalam surat Yusuf ayat 4, dan tentang melempar jumrah. Dan tentunya teori ini banyak memberikan sumbangsih dalam kajian islamic studies, misalnya seperti yang sudah dilakukan oleh Muhammad Arkoun dan Nashr Hamid Abu Zaid. 


\section{DAFTAR PUSTAKA}

H. Hoed, Benny. Semiotik dan Dinamika Sosial Budaya. Depok: Fakultas Ilmu Pengetahuan Budaya UI, 2008.

Imran, Ali. Kisah Nabi Yusuf Dalam Al-Qur'an; Kajian Semiotik. Yogyakarta:Teras, 2011.

Jurnal kolom edisi 046, Februari 2012, hlm. 3-5.

Kaelan. Filsafat Bahasa Semiotika dan Hermeneutika. Yogyakarta: Paradigma, 2009.

Piliang Yasraf Amir., Hipersemiotika Tafsir Cultural Studies Atas Matinya Makna. Yogyakarta: Jalasutra, 2010.

Sobur, Alex. Semiotika Komunikasi. Bandung: PT. Remaja Rosdakarya, 2006.

Sudjiman, Panuti dan Zoest, Aart Van. Serba-Serbi Semiotika. Jakarta: Gramedia Pustaka Utama, 1992.

Tinarbuko, Sumbo. Semiotika Komunikasi Visual. Yogyakarta: Jalasutra, 2008.

Wibowo, Indiwan Seto Wahyu. Semiotika; Aplikasi Praktis bagi Penelitian dan Penulisan Skripsi Ilmu Komunikasi. Jakarta: Fakultas Ilmu Komunikasi, 2006.

Zoest, Aart Van. Semiotika; Tentang Tanda, Cara Kerjanya dan Apa yang Kita Lakukan dengannya. Jakarta: Yayasan Sumber Agung, 1993. 